\title{
IMPACT OF QUALITY IMPROVEMENT IN PRIMARY SCHOOLS (QUIPS) PROGRAMME ON THE ACADEMIC PERFORMANCE OF PUPILS IN NEW EDUBIASE METHODIST PRIMARY SCHOOL IN THE ADANSI EAST DISTRICT OF GHANA
}

\author{
Osafo-Acquah, Aaron \\ Department of Basic Education, \\ University of Cape Coast. \\ Ghana \\ and \\ Asamoah-Gyimah, Kenneth \\ Department of Educational Foundations, \\ University of Cape Coast \\ Ghana \\ asamoagyima@yahoo.com
}

\begin{abstract}
Since the inception of Ghana's Educational Reform Programme in 1987, so many interventions have been put in place by the government and various donor organizations. Among them is the Quality Improvement in Primary School (QUIPS) programme sponsored by the USAID, which started in 1997, aimed at improving teaching and learning at the basic level. The purpose of the study was to determine the level of improvement in academic performance of pupils in New Edubiase Methodist Primary School since the inception of the QUIPS programme. It was also to find out what impact the programme has had on the teachers in the school as well as the assistance that the programme has given to parents and the community. The sample for the study included teachers of the New Edubiase Methodist Primary School and the parents who have their children in the school, numbering 58. The instruments used to collect data were questionnaire and interview. In analyzing the data, frequencies and percentages were used. The study revealed the following: The introduction of the QUIPS programme has helped to improve academic performance of the pupils in New Edubiase Methodist Primary School; The teachers in the school have improved their professional expertise through in-service training organized during the intervention; The parents and the community have also benefited indirectly from
\end{abstract}


the programme; and that the District Assembly has contributed towards the implementation of the QUIPS programme.

\section{Introduction}

The level of development of any country depends to a large extent on the level and quality of education of its citizens. It is against this background that the government of Ghana invested a total of 6.3 trillion cedis in education in the year 2005 (Source: Address by the Sector Minister - Mr. Osafo-Marfo at the 35th Congregation of UCC, March, 2005).

Since 1951, various governments of Ghana have attempted with varying degrees of success to provide quality basic education for all children starting with the Accelerated Development Plan for Education (1951). The Education Act of 1961, Kwapong Education Committee of 1967, Dzobo education committee of 1972, and the Education Commission's report in 1986 on Basic Education were part of the effort.

In 1983, the government of PNDC enacted PNDC Law 42 to modify and reinforce, among others, the Education Act of 1961 Section (1) subsection (g) of the law which directed that Educational facilities at all levels were to be provided and made available to the communities because it was the responsibility of the state to provide such facilities.

Provision of physical inputs such as textbooks, classrooms and inservicing training was intensified. While these inputs were necessary for the programme, they did not seem to be sufficient to transform the behaviour of the teachers and the learning of the pupils.

Though education is a "right and not a privilege" for the citizen as stated in the 1986 Education Commission report on basic education, it will be impracticable for the state to finance formal education for all its citizens. There are key players in the provision of basic education and these include: Central government, District, Municipal and Metropolitan Assemblies, private entrepreneurs and a number of International Funding Agencies (external donors). Some of these external donors are the World Bank through the International Development Association, United States through United States Agency for International Development (USAID). African Development Bank (ADB) and Japan International Development Agency (JICA).

The financing of quality education in Ghana caught the eye of the USAID, who assisted in the provision of quality education to the citizens of Ghana through the Quality Improvement in the Primary Schools (QUIPS) programme. QUIPS is USAID/Ghana's seven-year programme of assistance to basic education which began in 1997 to support Ghana's constitutionally mandated programme of free compulsory universal basic 
education. QUIPS was designed to develop, demonstrate and replicate the conditions and processes that are required for improving school standards and ultimately pupils' learning through out the education system by establishing model schools.

Each year, about 50 schools and communities are selected by the Ministry of Education to participate in the programme. Each cohort receives two years of interventions which occur at the community, school and district levels. These interventions promote the enabling environment, improve classroom instruction, improve school and district management and promote Community participation. It was expected that three hundred and thirty (330) schools would be reached by mid 2004 (source: QUIPS Mid-Term Assessment, March, 2001).

Through the QUIPS programme, teachers have been attending workshops and seminars so that their management and teaching skills would be improved. Parents and school management Committees have been invited to several meetings with the view to improving access and participation in the provision of education to all children. It is estimated that the QUIPS programme had a combined project worth Thirty five million US Dollars $(\$ 35 \mathrm{~m})$ and non-project assistance worth Eighteen million US Dollars ( $\$ 18 \mathrm{~m})$ to support education in Ghana including Adansi East District (source: QUIPS Mid-Term Assessment March, 2001). Despite all the in-service training and seminars for teachers, meetings and educating parents and school management committees and the District Assemblies, much had not been heard as to whether its objectives have been achieved or not.

The study was therefore an attempt to find the extent to which basic education has improved following the intervention of the QUIPS programme sponsored by USAID. The concern is the impact the QUIPS programme has made on the academic performance of pupils of New Edubiase Methodist primary school.

The purpose of the study was to determine the level of improvement in academic performance of pupils in New Edubiase Methodist primary school since the inception of the QUIPS programme. Again it was to find out the impact of the performance on teachers in the school of study and the assistance that the USAID has given to parents and the Community through QUIPS programme. 
The following research questions were used for the study

(i) To what extent has the academic performance of the pupils improved following the introduction of the QUIPS programme?

(ii) What assistance has QUIPS programme given to the parents and the community?

(iii) To what extent has the teachers' professional performance improved since the inception of the programme?

(iv) What effect has the QUIPS programme had on parents and community participation for mobilization of resources for basic education?

Hawes, (1981) views basic education as an idea and not a system. It is not conceived as three years, four years or six years but rather a set of basic skills, knowledge, attitude, and values that will enable learners to take charge of their own lives and set them free to learn further.

Agyeman (1986) throws more light on the importance of basic education and writes that the ultimate goal of basic education is to transmit to the educands the patterns of behaviour, the techniques of life, the values, the beliefs, the ideas and the knowledge which that particular society has accumulated and used.

The United Nations publication on selected demographic "characteristics of the world's children and youth" (1986) summarizes the importance of basic education and states that the declaration of the rights of the child recognizes the importance of basic education to the child. It stresses that, the child is entitled to receive education which shall be free and compulsory at least at the elementary level.

In October 1993, the Department of Primary Education was established under the sponsorship of the United States Agency for International Development (USAID) within the faculty of Education of University of Cape Coast (UCC) with the vision of preparing high calibre graduate professional teachers with special competencies to bring about quality primary school education and its efficient administration in Ghana. Education Act of 1961 shared the burden of funding education between the central government and district, municipal and metropolitan assemblies. Currently parents are requested to participate in the supply of textbooks to their wards to ensure a study supply hence the 
introduction of the textbooks fee which has now been cancelled at the basic level by the government.

Circuit Supervisor's Handbook (2002) revealed that from the 1997 criterion Referenced Test Conducted in Primary Six in 5\% of Primary Schools in Ghana, only $6.0 \%$ of the pupils attained mastery level in English language. The situation was even worse in Mathematics in which only $2.7 \%$ of the pupils attained mastery level. Furthermore, the 2000 and 2001 results of the performance Monitoring Test (PMT) conducted in Mathematics and English language in Adansi East District for Primary two to six pupils also showed evidence of low academic performance.

According to Banks (1989), NGOs are private organisations that pursue activities to relieve suffering, promote the interest of the poor, protect the environment, provide basic social services, or undertake community development. For instance since the inception of the Education Reform programme in 1987 approximately US\$400 million grants have been received by the education sector from the World Bank and other donor agencies to support the implementation of the reforms (Source: "Basic Education: A right" Programme for the provision of fCUBE by the year 2005, Dec 1994).

According to Hass and Parker (1953), an instructional material is any device that assists an instructor or teacher to transmit to the learner facts, skills, attitudes and knowledge. Instructional materials if properly used can increase the amount of trainee's learning from the period of instruction and speed up the whole training process. What learners look at and listen to are major factors in the effectiveness of learning.

Tamakloe, Amedahe and Atta (1996) support the idea that teaching and learning materials facilitate the learning process. They add that teaching resources are those materials that facilitate learning, understanding and acquisition of concepts, principles or skills by students. Learning resources on the other hand, are those materials that pupils use to make their learning easier.

The Honourable PNDC Secretary for Education and Culture, Dr. Ben Abdalla, (1987) in his statement on the Junior Secondary School (JSS) system, its implementation, and community participation, stated that it was the policy of the government that the JSS structure when implemented should mainly be the responsibility of the community to run with public funds.

According to the manual for school performance Appraisal meeting (Inspectorate Division, GES, Accra, February, 2000), unless the Ministry 
of Education and Ghana Education Service empower communities through legislation, information and education to take ownership of their schools and make teachers know and accept that they are accountable to the communities whose children they teach, it will be difficult to improve performance in public basic schools". This statement confirms the importance of school-community participation.

\section{Methodology}

\section{Sample}

Fifty-eight (58) respondents were sampled for the study. This was made up of one head teacher, twelve teaching staff and forty-five parents/guardians who have their children in the school. Five parents, comprising the chairman, secretary and three executive members of the school's Management Committee were purposively sampled because they were deemed to have in-depth knowledge of the QUIPS activities. In fact they were deeply involved in the implementation of QUIPS programme implementation in the district. The other 40 parent respondents were selected using the simple random sampling procedure in order to get the opinions of the members of the Parent Teachers Association about the QUIPS programme.

\section{Instrument}

The instruments used in the study were the interview guide, questionnaire and examination of documents. The interview guide was designed and administered to the parents whilst the questionnaire was designed for the teachers. The interview guide was made up of 15 items that sought specific views, opinions, and suggestions, related to the study. The questionnaire contained twelve (12) items. Ten (10) of the questions were close-ended and two (2) were open-ended. Results of the Performance Monitoring Test (PMT) conducted by the District Education Directorate in Mathematics and English Language for the 2000 and 2001 academic years were also collected and analyzed.

\section{Procedure for Data Collection}

The questionnaire was administered to the teachers and collected after a week's interval. The five executive members of the School Management Committee were interviewed and so were the forty parents.

\section{Data Analysis}

To make the data collected more meaningful and easy to interpret, percentage and frequency tables were drawn based on the various items 
of the research instrument. The mean of the students scores in the PMT were computed to enhance the understanding of the data collected.

\section{Results and discussion.}

Data was analyzed to establish the extent to which the academic performance of the pupils improved following the introduction of the QUIPS programme.

Table 1: Teachers response for pupils' academic performance

\begin{tabular}{|l|c|c|}
\hline \multicolumn{1}{|c|}{ Response } & Frequency & Percent \\
\hline Very High & 6 & 46.2 \\
\hline High & 7 & 53.8 \\
\hline Low & - & - \\
\hline Very Low & - & - \\
\hline Total & 13 & 100 \\
\hline
\end{tabular}

Table 1 revealed that 6(46.2\%) respondents said that academic performance was very high and $7(53.8 \%)$ respondents said it was high. This means that teachers saw the academic performance of the pupils as improving.

Table 2: Parents' response for pupils' academic performance

\begin{tabular}{|l|c|c|}
\hline \multicolumn{1}{|c|}{ Response } & Frequency & Percent \\
\hline Very High & 18 & 40 \\
\hline High & 27 & 60 \\
\hline Low & - & - \\
\hline Very Low & - & - \\
\hline Total & 45 & 100 \\
\hline
\end{tabular}

Table 2 also shows that $18(40 \%)$ parents said the academic performance of their pupils was very high whilst $27(60 \%)$ of the parents said it was high. It is evident from the parents that, the academic performance of the pupils was improving.

The introduction of the QUIPS programme by USAID is helping greatly in pupils' academic performance. The interventions of QUIPS have promoted the enabling environment, improved classroom 
instruction, improved School Management, hence the good performance of the pupils.

This confirms the assertion that QUIPS programme targets a limited number of schools with activities to improve the learning environment, increase the effectiveness of teaching through improved methods and assistance, and increased community involvement in education, all to support the government's fCUBE programme.

Table 3: PMT results of the first ten primary schools for Adansi East District Mathematics (2000)

\begin{tabular}{|c|c|c|c|c|c|c|c|c|}
\hline \multirow[t]{2}{*}{ Position } & \multirow[t]{2}{*}{ Name of School } & \multicolumn{2}{|c|}{$\begin{array}{l}\text { Sample } \\
\text { Score }\end{array}$} & \multicolumn{2}{|c|}{ Total Score } & \multicolumn{2}{|c|}{$\begin{array}{l}\text { Mean } \\
\text { School }\end{array}$} & \multirow[t]{2}{*}{ Score } \\
\hline & & $\mathrm{M}$ & $\mathrm{F}$ & $\mathrm{M}$ & $\mathrm{F}$ & M & $\mathrm{F}$ & \\
\hline 1 & New Edubiase Meth Prim. 'B' & 18 & 20 & 1330 & 1260 & 73.9 & 63.0 & 68.5 \\
\hline 2 & New Edubiase L/A Prim. 'B' & 16 & 13 & 1060 & 840 & 66.3 & 64.6 & 65.5 \\
\hline 3 & Pewodie L/A Primary & 24 & 22 & 1575 & 1420 & 63.0 & 64.5 & 63.8 \\
\hline 4 & Amudurase L/A Primary & 24 & 22 & 1590 & 1250 & 66.3 & 56.8 & 61.6 \\
\hline 5 & New Edubiase Meth. Prim. 'A' & 23 & 25 & 1490 & 1365 & 64.8 & 54.6 & 59.7 \\
\hline 6 & Atobiase R/C Primary 'B ' & 10 & 8 & 710 & 360 & 70.0 & 45.0 & 57.5 \\
\hline 7 & Biakwaso L/A Primary & 19 & 15 & 780 & 560 & 70.9 & 43.5 & 57.0 \\
\hline 8 & Akwansrem R/C Primary & 22 & 22 & 1360 & 1135 & 61.8 & 51.6 & 56.7 \\
\hline 9 & New Akrofuom L/A Primary & 27 & 25 & 1465 & 1270 & 54.3 & 54.2 & 54.3 \\
\hline 10 & New Edubiase L/A Primary 'A' & 15 & 15 & 955 & 770 & 66.3 & 40.0 & 53.0 \\
\hline
\end{tabular}

Source: Adansi East District Education Office

The data in Table 3 reveals that the two streams of New Edubiase Methodist Primary School were among the first ten schools in 2000 PMT mathematics results for the district. The ' $\mathrm{B}$ ' stream was first and the 'A' stream was fifth.

Table 4: PMT results for English Language 2000

\begin{tabular}{|c|l|c|c|c|c|c|c|l|}
\hline \multirow{2}{*}{ Position } & \multirow{2}{*}{ Name of School } & \multicolumn{2}{|c|}{$\begin{array}{c}\text { Sample } \\
\text { Score }\end{array}$} & \multicolumn{2}{|c|}{ Total Score } & \multicolumn{2}{|c|}{$\begin{array}{c}\text { Mean } \\
\text { School }\end{array}$} & \multirow{2}{*}{ Score } \\
\cline { 3 - 9 } & & $\mathrm{M}$ & $\mathrm{F}$ & $\mathrm{M}$ & $\mathrm{F}$ & $\mathrm{M}$ & $\mathrm{F}$ & \\
\hline 1 & Fumso R/C Prim 'B' & 26 & 22 & 1910 & 1700 & 73.5 & 77.2 & 75.4 \\
\hline 2 & New Edubiase Meth. Primary 'B' & 17 & 21 & 1340 & 1505 & 78.8 & 71.7 & 75.3 \\
\hline 3 & New Edubiase Meth. Primary 'A' & 21 & 26 & 1425 & 1845 & 67.9 & 70.9 & 69.4 \\
\hline 4 & New Edubiase L/A Primary 'B' & 16 & 13 & 1120 & 805 & 70.0 & 61.9 & 66.0 \\
\hline 5 & Amudurase L/A Primary & 26 & 22 & 1740 & 1300 & 66.3 & 56.8 & 61.6 \\
\hline 6 & Ahomahoma L/A Primary & 17 & 13 & 1040 & 760 & 61.2 & 58.5 & 60.3 \\
\hline 7 & Fumaso R/C Primary 'A' & 25 & 21 & 1450 & 1085 & 58.0 & 51.7 & 54.9 \\
\hline
\end{tabular}




\begin{tabular}{|c|l|c|c|c|r|r|r|l|}
\hline 8 & New Edubiase L/A Primary 'A' & 14 & 16 & 845 & 760 & 60.0 & 47.5 & 53.6 \\
\hline 9 & Saponso-Mem L/A Primary & 11 & 10 & 645 & 450 & 58.6 & 45.0 & 51.8 \\
\hline 10 & MENANG L/A Primary & 27 & 27 & 200 & 1305 & 44.3 & 48.3 & 46.4 \\
\hline
\end{tabular}

Source: Adansi East District Education Office.

Table 4 shows that in 2000 PMT for English Language, the two streams were among the first ten schools in the district. The ' $\mathrm{B}$ ' stream was second and 'A' stream took the third position.

Table 5: PMT results for Mathematics (2001)

\begin{tabular}{|c|c|c|c|c|c|c|c|c|}
\hline \multirow{2}{*}{ Position } & \multirow{2}{*}{ Name of School } & \multicolumn{2}{|c|}{$\begin{array}{l}\text { Sample } \\
\text { Score }\end{array}$} & \multicolumn{2}{|c|}{ Total Score } & \multicolumn{2}{|c|}{ Mean School } & \multirow[t]{2}{*}{ Score } \\
\hline & & $\mathrm{M}$ & $\mathrm{F}$ & $\mathrm{M}$ & $\mathrm{F}$ & $\mathrm{M}$ & $\mathrm{F}$ & \\
\hline 1 & New Edubiase Meth. Primary 'A' & 50 & 50 & 4427 & 4337 & 83.54 & 86.74 & 85.17 \\
\hline 2 & New Edubiase Meth. Primary 'B' & 50 & 50 & 4192 & 4292 & 83.96 & 85.88 & 84.92 \\
\hline 3 & New Edubiase L/A Primary 'B' & 53 & 43 & 4182 & 3521 & 79.90 & 81.02 & 80.46 \\
\hline 4 & Kojo Nkwanta L/A Primary & 53 & 39 & 4367 & 2770 & 83.00 & 71.48 & 77.69 \\
\hline 5 & Atwereboaba L/A Primary & 50 & 50 & 4233 & 3574 & 84.66 & 69.48 & 77.07 \\
\hline 6 & New Edubiase L/A Primary 'A' & 57 & 37 & 4199 & 2869 & 79.22 & 70.60 & 74.91 \\
\hline 7 & Asarekrom L/A Primary & 37 & 41 & 2717 & 3143 & 73.43 & 69.68 & 71.56 \\
\hline 8 & Kweku Adu L/A Primary & 41 & 30 & 2914 & 2268 & 71.07 & 69.57 & 70.32 \\
\hline 9 & Akwansarem R/C 'B' & 50 & 50 & 3796 & 3484 & 70.02 & 68.64 & 69.33 \\
\hline 10 & Atobiase R/C 'B' & 32 & 28 & 2399 & 1948 & 70.90 & 67.64 & 69.27 \\
\hline
\end{tabular}

Source: Adansi East District Education Office

Table 5 reveals that in 2001 PMT for Mathematics, New Edubiase Methodist Primary Schools ' $A$ ' and ' $B$ ' took the $1^{\text {st }}$ and $2^{\text {nd }}$ positions respectively.

Table 6: PMT results for English Language (2001)

\begin{tabular}{|c|c|c|c|c|c|c|c|c|}
\hline \multirow{2}{*}{$\begin{array}{l}\text { Posi } \\
\text { tion }\end{array}$} & \multirow[t]{2}{*}{ Name of School } & \multicolumn{2}{|c|}{$\begin{array}{l}\text { Sample } \\
\text { Score }\end{array}$} & \multicolumn{2}{|c|}{ Total Score } & \multicolumn{2}{|c|}{$\begin{array}{l}\text { Mean } \\
\text { School }\end{array}$} & \multirow[t]{2}{*}{ Score } \\
\hline & & $\mathrm{M}$ & $F$ & $\mathrm{M}$ & $F$ & $\mathrm{M}$ & $\mathrm{F}$ & \\
\hline 1 & $\begin{array}{l}\text { New Edubiase Meth. } \\
\text { Primary 'A' }\end{array}$ & 50 & 50 & 4195 & 3920 & 83.90 & 81.20 & 82.56 \\
\hline 2 & $\begin{array}{l}\text { New Edubiase Meth. } \\
\text { Primary 'B' }\end{array}$ & 50 & 50 & 3810 & 4160 & 76.20 & 83.20 & 79.70 \\
\hline 3 & $\begin{array}{l}\text { Asarekrom L/A Primary } \\
\text { 'A' }\end{array}$ & 37 & 41 & 2746 & 2883 & 74.20 & 70.30 & 72.25 \\
\hline
\end{tabular}




\begin{tabular}{|c|c|c|c|c|c|c|c|c|}
\hline \multirow{2}{*}{$\begin{array}{l}\text { Posi } \\
\text { tion }\end{array}$} & \multirow[t]{2}{*}{ Name of School } & \multicolumn{2}{|c|}{$\begin{array}{l}\text { Sample } \\
\text { Score }\end{array}$} & \multicolumn{2}{|c|}{ Total Score } & \multicolumn{2}{|c|}{$\begin{array}{l}\text { Mean } \\
\text { School }\end{array}$} & \multirow[t]{2}{*}{ Score } \\
\hline & & $\mathrm{M}$ & $\mathrm{F}$ & $\mathrm{M}$ & $\mathrm{F}$ & $\mathrm{M}$ & $\mathrm{F}$ & \\
\hline 4 & $\begin{array}{l}\text { New Edubiase } \mathrm{L} / \mathrm{A} \\
\text { Primary ' } \mathrm{B} \text { ' }\end{array}$ & 53 & 43 & 3853 & 3058 & 72.70 & 71.10 & 71.19 \\
\hline 5 & Amudurase L/A Primary & 50 & 50 & 3815 & 3186 & 76.30 & 63.70 & 70.00 \\
\hline 6 & Wuruyie L/A Primary & 57 & 37 & 3985 & 2486 & 69.80 & 67.20 & 68.50 \\
\hline 7 & Kaperekrom Primary 'A' & 27 & 15 & 1860 & 918 & 68.50 & 61.20 & 64.85 \\
\hline 8 & Acheasewa L/A Primary & 42 & 47 & 2875 & 2748 & 68.90 & 58.50 & 63.37 \\
\hline 9 & $\begin{array}{llll}\text { Tonkoase } & \text { No } & 1 & \text { L/A } \\
\text { Primary } & & & \\
\end{array}$ & 48 & 45 & 3021 & 2753 & 64.00 & 61.70 & 62.85 \\
\hline 10 & $\begin{array}{l}\text { New Edubiase L/A } \\
\text { Primary ' } A \text { ' }\end{array}$ & 53 & 41 & 3332 & 2391 & 64.40 & 58.30 & 59.35 \\
\hline
\end{tabular}

Source: Adansi East District Education Office

Table 6 shows that in 2001 PMT results for English Language, the streams 'A' and 'B' of the New Edubiase Methodist Primary School took the $1^{\text {st }}$ and the $2^{\text {nd }}$ positions respectively.

The introduction of QUIPS programme by USAID in 1998 has improved the academic performance of pupils of New Edubiase Methodist Primary School. The performance has provided the school with textbooks, exercise books, and teaching-learning materials.

The following findings were made from the study:

(a) Funding of basic education should not be the sole responsibility of the central government

(b) Good teaching methods and teacher instruction enhance learning

(c) The provision and use of teaching and learning materials are of great importance in teaching and learning, hence improvement in academic performance of pupils

\section{Discussion of Findings}

The study showed that funding of education should not be the sole responsibility of the central government. The introduction of the QUIPS programme by USAID is helping greatly in pupils' academic performance. For instance, in 1998, the programme was introduced in New Edubiase Methodist Primary and teachers in the school were given several in-service training, seminars and workshops to sharpen their skills, thereby improving the academic performance of the pupils of the school. 
The QUIPS programme has also provided the school with infrastructure, textbooks, exercise books and teaching learning materials. This supports the "Basic Education - A Right" programme in which about 400 million dollars was donated by the World Bank and other donor agencies for developing basic education (Source: "Basic Education - A Right programme for provision of fCUBE by the year 2005). Again, from the QUIPS Mid-Term Assessment, March, 2001, it was stated that 53 million dollars was used to support Ghana's basic education including the New Edubiase Methodist Primary School.

The study also showed that good teaching methods and teacher instruction enhance learning. Results of the PMT in Mathematics and English Language for Adansi East District showed that the teachers at New Edubiase Methodist Primary School showed mastery and understanding of subject matter that they taught. The academic performance of the pupils changed from year to year. Tables 3, 4, 5, and 6 support the fact that the academic performance of the pupils changed each year. For example in Table 3, New Edubiase Methodist Primary took the $1^{\text {st }}$ and $5^{\text {th }}$ positions in PMT for Mathematics and English in 2000. In tables 5 and 6, the school placed $1^{\text {st }}$ and $2^{\text {nd }}$ in 2001 PMT Mathematics and English Language.

\section{Conclusion}

It is obvious that the QUIPS programme has had positive impact on the pupils and teachers of New Edubiase Methodist Primary School. The improvement in the infrastructure and material resources in the school has brought about effective teaching and learning and this has resulted in improvement in pupils' academic performance.

The QUIPS programme, sponsored by USAID has therefore been a source of relief to parents whose children are in the school since the programme supplied the school with textbooks and exercise books. The in-service training and seminars which were organized by the implementers for the teachers have improved their personal and professional growth hence the improved performance of the pupils.

\section{Recommendations}

Based on the findings of this research, the following recommendations are made: 
1. Government should put in place good policies to allow more external donors to assist in the funding of basic education.

2. In-service Training should be organized frequently for teachers in all schools to upgrade teachers' professional growth.

3. Agencies, individuals, philanthropists, commercial houses and Non-governmental organizations should emulate USAID. This will help solve the problem of shortage of textbooks, poor infrastructure and outmoded methods of teaching which result in poor academic performance of pupils.

\section{References}

Agyeman, D.K. (1986). Sociology of Education for African Students. Accra: Black mask Ltd. Bacon Inc.

Bank Olive (1989). Non-Governmental Organization in World Bank supported projects; Washington D.C.

Brookman-Amissah, J. (1992). Introduction to Education in Ghana. Accra: Assemblies of God Literature Ltd.

Chapman, L. (1966). Community Participation in Education. London: Allyn and Dictionary of Education 1950) page 548

GES (2000). Manual for school performance Appraisal Meeting. Accra.

Ghana Government. (2003). Presidential Review Committee on Education Reports, Meeting the challenges of 21st Century, Accra Ghana

Hagan, J. (1984). Teaching History Vol. 2 New Dezhi; Vikas Publishing House.

Hawes, W.R. (1981). Planning the Primary School Curriculum in Developing Countries, London. Macmillan Publishers Ltd.

Koff, H.W. (1967). Curriculum and Instruction. Kenya: Kegan Paul Ltd.

Ministry of Finance (2005) National Budget Statement, Ghana.

MOE/GEES (1994) Basic Education a Right, Programme for the Provision of FCUBE by the year 2005. Accra: Government of Ghana.

MOE/GES. (2002). Circuit Supervisor's Handbook, Accra; Ghana.

Quansah, J.C. (2000). Moves to boost Education, Daily Graphic March 11 pg. 24

QUIPS Mid-Term Assessment (2001)

Sherleker, J.S. (1984). The Theory and Practice of Educational Administration. London: Macmillan Publishes.

Stone, J. E. (1984). Management and Organizational Behaviour. New York: Harper and Row

Tamakloe et al (1996). Principles and Methods of Teaching, Accra; Black Mask Ltd. 
The Oxford Advanced Learners Dictionary (1998), Page 919; 5th Edition London: Oxford Press.

The Primary Teacher (April, 1987). News letter from the Department of Primary Education - UCC Ghana

United Nations. (1986). Publication on Selected Demographic "Characteristics of the World's children and youth" page 57

Webster Encyclopaedia of Dictionaries (1958) page 1204. 